\title{
The new database of the Global Terrestrial Network for Permafrost (GTN-P)
}

\author{
B. K. Biskaborn ${ }^{1}$, J.-P. Lanckman ${ }^{2}$, H. Lantuit ${ }^{1,3}$, K. Elger $^{4}$, D. A. Streletskiy ${ }^{5}$, W. L. Cable ${ }^{6}$, and \\ V. E. Romanovsky 6,7 \\ ${ }^{1}$ Alfred Wegener Institute Helmholtz Centre for Polar and Marine Research, Potsdam, Germany \\ ${ }^{2}$ Arctic Portal, Akureyri, Iceland \\ ${ }^{3}$ Institute for Earth and Environmental Sciences, University of Potsdam, Potsdam, Germany \\ ${ }^{4}$ Helmholtz Centre Potsdam GFZ German Research Centre for Geosciences, Potsdam, Germany \\ ${ }^{5}$ Department of Geography, The George Washington University, Washington, USA \\ ${ }^{6}$ Geophysical Institute, University of Alaska Fairbanks, Fairbanks, USA \\ ${ }^{7}$ Earth Cryosphere Institute, Tyumen, Russia \\ Correspondence to: B. K. Biskaborn (boris.biskaborn@awi.de)
}

Received: 15 February 2015 - Published in Earth Syst. Sci. Data Discuss.: 9 March 2015

Revised: 20 July 2015 - Accepted: 21 July 2015 - Published: 14 September 2015

\begin{abstract}
The Global Terrestrial Network for Permafrost (GTN-P) provides the first dynamic database associated with the Thermal State of Permafrost (TSP) and the Circumpolar Active Layer Monitoring (CALM) programs, which extensively collect permafrost temperature and active layer thickness (ALT) data from Arctic, Antarctic and mountain permafrost regions. The purpose of GTN-P is to establish an early warning system for the consequences of climate change in permafrost regions and to provide standardized thermal permafrost data to global models. In this paper we introduce the GTN-P database and perform statistical analysis of the GTN-P metadata to identify and quantify the spatial gaps in the site distribution in relation to climate-effective environmental parameters. We describe the concept and structure of the data management system in regard to user operability, data transfer and data policy. We outline data sources and data processing including quality control strategies based on national correspondents. Assessment of the metadata and data quality reveals $63 \%$ metadata completeness at active layer sites and $50 \%$ metadata completeness for boreholes.

Voronoi tessellation analysis on the spatial sample distribution of boreholes and active layer measurement sites quantifies the distribution inhomogeneity and provides a potential method to locate additional permafrost research sites by improving the representativeness of thermal monitoring across areas underlain by permafrost. The depth distribution of the boreholes reveals that $73 \%$ are shallower than $25 \mathrm{~m}$ and $27 \%$ are deeper, reaching a maximum of $1 \mathrm{~km}$ depth. Comparison of the GTN-P site distribution with permafrost zones, soil organic carbon contents and vegetation types exhibits different local to regional monitoring situations, which are illustrated with maps. Preferential slope orientation at the sites most likely causes a bias in the temperature monitoring and should be taken into account when using the data for global models. The distribution of GTN-P sites within zones of projected temperature change show a high representation of areas with smaller expected temperature rise but a lower number of sites within Arctic areas where climate models project extreme temperature increase.

GTN-P metadata used in this paper are available at doi:10.1594/PANGAEA.842821.
\end{abstract}




\section{Introduction}

Warming of the cryosphere is likely to exceed the global average temperature increase (ACIA, 2004; Groisman and Soja, 2009; IPCC, 2013; Miller et al., 2010). Permafrost is defined as ground that remains frozen for at least two consecutive years (Van Everdingen, 1998). Ongoing permafrost warming (Romanovsky et al., 2010b) and near-surface thawing in permafrost regions associated with rising air temperatures are considered to reinforce warming of the atmosphere through the conversion of the large soil organic carbon pool in permafrost into greenhouse gases, a process termed "permafrost carbon feedback" (Grosse et al., 2011; Hugelius et al., 2013; Schaefer et al., 2014; Schuur et al., 2013). Worldwide monitoring of permafrost is essential to understand the impact of climate change on its thermal state and to assess the impact of permafrost thaw on the Earth climate system. Hence, international collaboration on data collection and analyses is a great challenge to overcome in this advancing scientific problem of global concern. Addressing the demands of data providers, data managers, and data users is imperative to enable the reliable creation of growing data sets. Moreover the willingness of scientists to share data and to participate in data management strategies are crucial requirements for scientific advancement (Papale et al., 2012).

The monitoring of essential climate variables (ECVs) for permafrost (Fig. 1) has been delegated to GTN-P by the World Meteorological Organization (WMO) global observing community (www.wmo.int/pages/prog/gcos/). GTN$\mathrm{P}$ established permafrost temperature and active layer thickness (ALT) as ECVs related to two specific monitoring programs: (i) TSP (Thermal State of Permafrost) and (ii) CALM (Circumpolar Active Layer Monitoring) (Romanovsky et al., 2010b; Shiklomanov et al., 2012). Formerly known as GTNet-P, GTN-P was developed in 1999 by the International Permafrost Association (IPA) with active support by the Canadian Geological Survey (Brown et al., 2000; Burgess et al., 2000) under the Global Climate Observing System (GCOS) and the Global Terrestrial Observing Network (GTOS).

The growing number of high-resolution measurements and annual collection of permafrost data clearly prompted the need for comprehensive management of the GTN-P, including its data management system. Several databases exist for particular regions in Europe (Juliussen et al., 2010; PERMOS, 2013). While the permafrost data from the USA are archived with ACADIS (Advanced Cooperative Arctic Data and Information Service), which took over for the former CADIS (Cooperative Arctic Data and Information Service) as a repository for all data from National Science Foundation (NSF)-funded Arctic research. A good example of DOI-referenced data publication is Nordicana D, an online data report series of the Canadian Centre d'études Nordiques (CEN), including long-term time series of permafrost borehole temperatures (Allard et al., 2014).

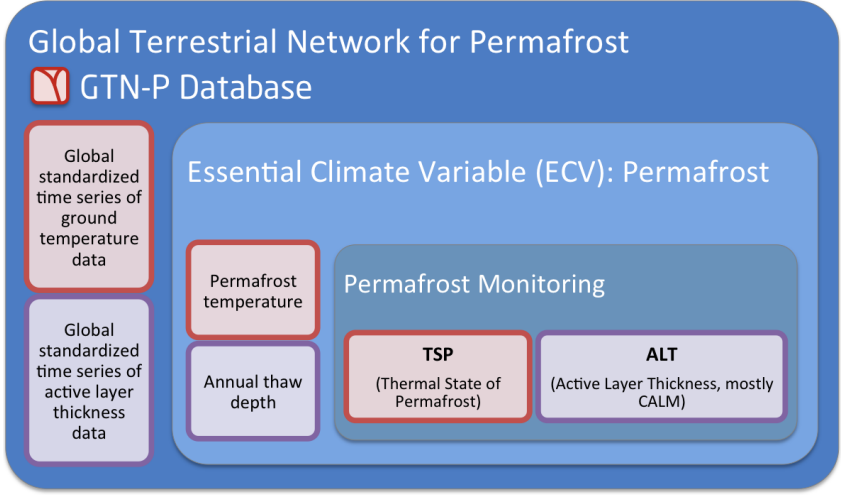

Figure 1. Framework within the Global Terrestrial Network for Permafrost defined by permafrost temperature and active layer thickness (ALT) data collected by the TSP and CALM programs, respectively.

The GTN-P experienced substantial growth at the beginning of the 21st century. About 350 boreholes for temperature monitoring were established and a considerable number of active layer depth observations were collected during the 4th International Polar Year (IPY) from March 2007 to March 2009 (Brown, 2010). Efforts of the IPA and the GTN$\mathrm{P}$ at the end of the IPY resulted in reports on the thermal state of permafrost in high latitudes and high altitudes which were called the "IPA snapshot" (Christiansen et al., 2010; Romanovsky et al., 2010a; Smith et al., 2010; Vieira et al., 2010; Zhao et al., 2010). The Geological Survey of Canada (GSC) also invested great efforts in collecting and storing thermal permafrost data from the western Arctic for GTN-P.

The TSP (Brown et al., 2010) and CALM (Shiklomanov et al., 2008) programs oversee the collection of permafrost temperature and active layer thickness data from Arctic, Antarctic and mountain permafrost regions. These programs provide the majority of the content to the GTN-P Database (Fig. 1). Both TSP and CALM provide an online data repository and are actively expanding observational networks. However, all existing permafrost repositories so far were conceived as rather static aggregations of data, and the modern permafrost community lacks a dynamic database with the capability to interlink the permafrost community and scientists working in other fields of research such as climate modelers, biologists or engineers.

The long-term goal of GTN-P is to obtain a comprehensive view of the spatial structure, trends and variability in permafrost temperature as well as active layer thickness (GTN$P, 2012)$. The international network of permafrost observatories will provide an early warning system for the impacts of climate change in permafrost regions (Romanovsky et al., 2010b) and provide standardized permafrost data needed as input to global climate models.

In this paper, we introduce the first dynamic database for parameters measured by the GTN-P. The new GTN-P 
Database is a state-of-the-art tool for storing, processing and sharing parameters relevant to the permafrost ECV measured in the Arctic, Antarctic and mountain regions. It is hosted at the Arctic Portal in Akureyri (Iceland) and managed in close cooperation with the Alfred Wegener Institute, Helmholtz Centre for Polar and Marine Research (AWI), in Potsdam (Germany) and supported by the European Union Seventh Framework Programme project PAGE21.

The specific objectives of this paper are (i) to describe the framework of the GTN-P Data Management System, (ii) to provide statistics on site distribution in the GTN-P by performing spatial analyses on the metadata, and (iii) to identify spatial gaps in the GTN-P site distribution and compare the results with relevant environmental geospatial data sets.

\section{Description of the data management system}

\subsection{Database design and principles}

The GTN-P Database (GTN-P, 2015) is accessible online at http://gtnpdatabase.org or through the GTN-P website at http://www.gtnp.org. The general framework of the GTN-P Data Management System (DMS) is based on open source technologies following an object-oriented data model (Fig. 2) implemented with CakePHP and the database PostGIS, the spatial version of PostgreSQL (Obe and Hsu, 2011). The database distinguishes between permafrost temperatures and annual thaw depths (i.e., active layer depths). To ensure interoperability and enable inter-database searching, metadata field names are based on a controlled vocabulary registry. The documentation of the DMS is available and regularly updated on gtnp.org (ISSN 2410-2385) as the database framework and content evolves.

The online interface of the GTN-P Database was developed to maximize usability both for the data provider and user. The resulting roles (data administrator, data provider and data user) are built into the database, providing different rights to read, edit or modify data. Data users can access the database without an account and password and have access to (i) permafrost temperatures, (ii) annual thaw depths and (iii) help sections. While administrators have full access, data providers cannot modify or delete data of third parties. Data not marked as "published" by the data providers are not accessible to third parties or the public. The help section provides tutorials and template files for upload and download of borehole temperature and active layer grid data as well as GTN-P maps and fact sheets.

GTN-P follows an open-access policy in line with the IPY data policy and the GEO (Group on Earth Observations) data-sharing principles. The GTN-P Steering Committee decided on a general embargo period of 1 year. This means that data from 2015 will be available at the earliest in 2016 in order to allow investigators the first opportunity to publish their data. For special cases, e.g., doctoral dissertations, this embargo may be extended on demand. The data will be made freely available to the public and the scientific community with the belief that their wide dissemination will lead to greater understanding and new scientific insights because global scientific problems require international cooperation. Data download is unrestricted and requires only a free registration needed for web security reasons. Before being able to download data, users must accept the terms and conditions of the data use policy. Therein, the user is asked to contact the site PIs prior to publication to prevent potential misuse or misinterpretation of the data. In addition, an email is automatically sent to the contact person of each data set downloaded to inform them of the interest in the data.

\subsection{Data collection, browsing and publication}

A thorough data mining effort was conducted prior to the creation of the GTN-P Database. The recovered data sets were characterized by an extreme diversity. These included global data sets on active layer thickness from the CALM data collection (Shiklomanov et al., 2008), as well as data sets aggregated thematically, geographically or institutionally. Data providers include the Advanced Cooperative Arctic Data and Information Service (www.aoncadis.org) at the National Snow and Ice Data Center (http://nsidc.org), the Permafrost Laboratory (University of Alaska Fairbanks), NORPERM (Juliussen et al., 2010) and PERMOS (PERMOS, 2013), among others. Part of the data was provided by individual permafrost research groups and relayed into the database by the GTN-P national correspondents (NCs). In addition to GTN-P standard data sets on temperature and active layer thickness, several ancillary existing data sets were opportunistically added to the database. These include in particular remotely sensed land surface temperature and surface soil moisture values that were transferred from ESA DUE Permafrost (Bartsch and Seifert, 2012; DUE Permafrost Project Consortium, 2012).

The data upload procedure was conceived to eliminate the need for any prior knowledge of databases by the user. NCs from all participating countries were nominated by the national committees and by the scientific international permafrost community to provide data on an annual basis, collecting information from the investigators and data managers from that country. NCs are listed on the GTN-P website and can be contacted by permafrost researchers interested in contributing monitoring data to the GTN-P Database. NCs are also encouraged by the GTN-P Steering Committee to proactively engage national investigators in the process to ensure a continuous upload of data into the system. The requirements of the data upload are compliant with existing international standards for geospatial metadata ISO 19115/2 and TC/221 (www.iso.org). The database specifically builds on the GTN-P metadata form that was developed as a standard by the GTN-P leadership in 1999 (Burgess et al., 2000). Site metadata must be entered and selected from parameters and properties, which are selectable in drop-down lists in 


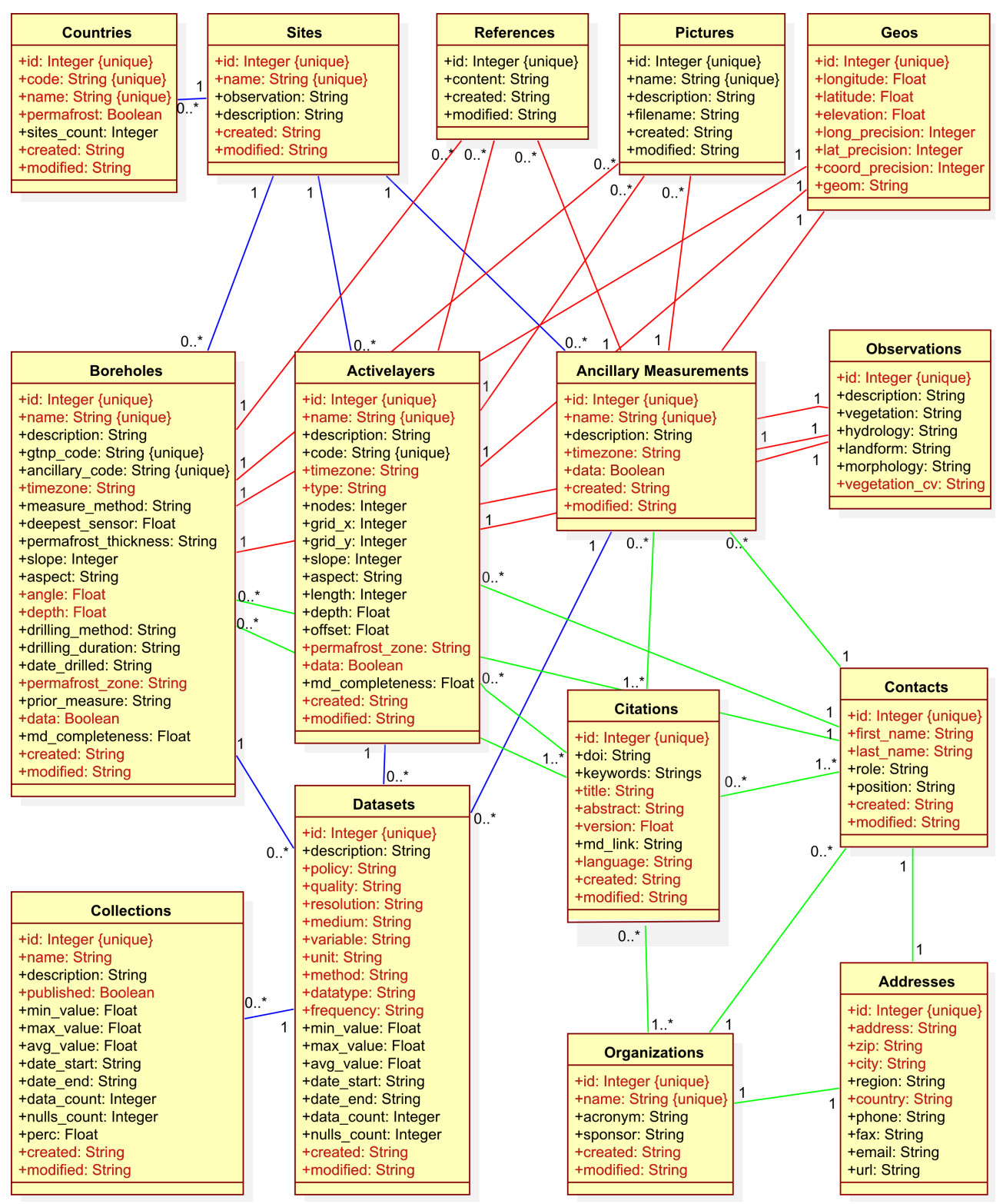

Figure 2. UML (Unified Modeling Language) diagram of the object-oriented GTN-P Data Management System and its classes, cardinalities and metadata (mandatory metadata in red).

the upload interface. GTN-P metadata used in this paper are available at doi:10.1594/PANGAEA.842821 (GTN-P, 2015). Tutorials and templates of data files provide the necessary information to bring the data into the right CSV (commaseparated values) format, prior to data upload. The maximum file size for upload is $1.5 \mathrm{MB}$.

The GTN-P Database features both (i) basic search and (ii) custom search functions. The goal of these functions is to narrow down the number of data records based on a set of criteria. While the basic search is a simple filter by manual character input, the advanced custom search allows the use of multiple search criteria to retrieve a defined list of data records from the repository. The data and metadata as- sociated with the search results can be downloaded by the data user as compressed file packages containing standardized metadata forms in text and XML (Extensible Markup Language) and the corresponding data in CSV format. However, the CSV format and the inconsistency of the time series, in regard to completeness, frequency and geometry, do not facilitate their direct use within climate models, as they do not comply with the CF (Climate and Forecast) 1.6 convention. Therefore, the GTN-P as well as other global terrestrial networks should link processes, structures and technologies with existing marine and atmospheric networks, aiming at close cooperation for their assimilation into climate models. Data heterogeneity in terms of spatial variability, frequency, 
measurement profile and methods complicates data gridding. To address this issue, we developed tools for data analysis, processing and quality assurance, through the data model definition and a set of internal database triggers, functions and a SQL-to-NetCDF Python converter. Measurement frequencies and methods, sampling profiles, values and null values count, time series first and last date, time gaps, total and annual minimum, maximum, average, standard deviation and variance are systematically retrieved during the data upload. TSP data sets are linearly interpolated at consistent $0,1,2$, 3,5 , and $10 \mathrm{~m}$ borehole depths. All eligible data sets are aggregated into a NetCDF (Network Common Data Form) file. Conventions for CF 1.6 metadata are designed to promote the processing and sharing of files created with the NetCDF Application Programmer Interface and provides a definitive description of the spatial and temporal properties of the data. The resulting NetCDF files represent (i) a TSP data set in a multidimensional array representation of annual time series profiles of ground temperature, orthogonal along vertical and orthogonal along time, and (ii) a CALM data set in an orthogonal multidimensional array representation of annual times series of active layer thickness.

\subsection{Amount of data in GTN-P}

At the time of submission of this paper the GTN-P Database contained metadata from 1074 TSP boreholes and 243 ALT monitoring sites, out of which 239 are taken from the CALM database. Thirty-one boreholes are located in the mountain permafrost regions and 72 in Antarctica. Currently, 277 borehole sites have temperature data and 78 active layer monitoring sites have annual thaw depth data. Due to the fact that one site can have more than one measurement unit or period, the total number of data sets differs from the number of sites: 1062 ground temperature data sets (including surface and air temperature); 78 active layer thickness data sets; and 160 extra data sets with surface soil moisture from satellite measurements, boreholes, and active layers sites.

\section{Data quality concept}

\subsection{Data quality control}

In addition to the data quality control of the individual permafrost scientist, the GTN-P Data Management System offers quality control. Data being entered into the database undergo several steps of quality checking before receiving approval for data output. To harmonize the different data formats and produce one standard format within the GTN-P Database, every data set retrieved from external sources underwent a review and a standardization procedure to bring the file into the correct format for upload. This includes, in particular, conversion of file structures, date formats, reference points and null values. Metadata input must be compliant with the database rules and include a number of manda-

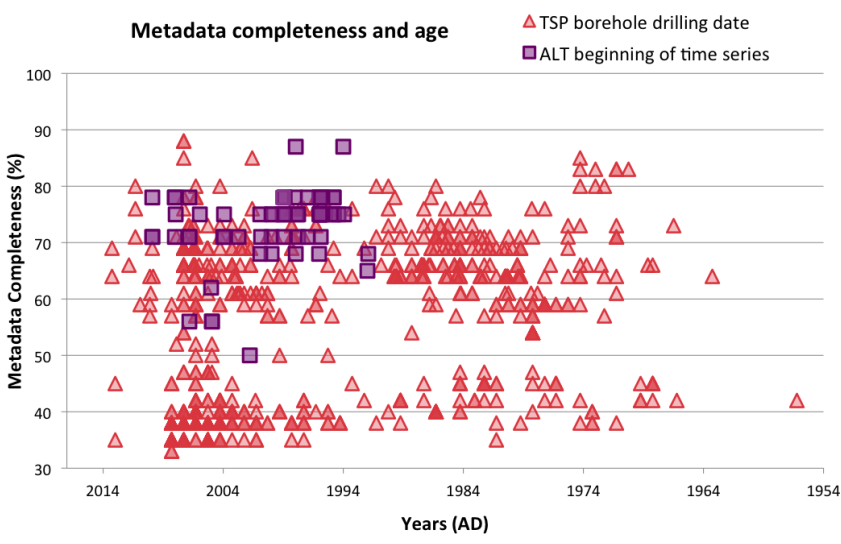

Figure 3. Metadata completeness in percent of filled-in metadata fields for TSP (1074 boreholes) and ALT (243 active layer monitoring sites) vs. the borehole drilling date or the first measurement of ALT time series, respectively.

tory fields employing terminology code lists and controlled vocabulary associated with the GTN-P Database (Fig. 2) as documented on the GTN-P website. Successful upload assures correctness and consistency of the data set. Screening for obvious errors follows with the help of automated data visualization during and after the upload procedure. Interactive and adjustable data plots on the database website serve also as on-the-fly data visualization for scientific purposes. According to the GTN-P Strategy and Implementation Plan 2012-2016 (GTN-P, 2012) metadata and data considered for input into the GTN-P Database will be coordinated and reviewed by NCs on a regular basis, at least once per year. Quality checked data sets are published only after approval by the NCs, who are responsible for the quality assessment of permafrost data from their countries.

\subsection{General quality assessment and limits}

In geoscience, errors start to emerge as early as at the measurement stage. The most common technique of continuously recording borehole ground temperatures at specific depths is the use of permanently installed multi-thermistor cables, providing an accuracy and precision between ca. 0.02 and $0.1{ }^{\circ} \mathrm{C}$ (Brown et al., 2000; Romanovsky et al., 2010b). The logger resolution and measurement frequency, however, varies with the type and the depth of the individual borehole. Due to active layer dynamics, the relative vertical position of measurement probes can change and hence introduce an error into the depth indications of old boreholes in sensitive areas. Additionally, the number of vertical positions of sensors varies not only between and within boreholes (and research groups) but also through time. Commonly, sensors are placed every $0.2-0.4 \mathrm{~m}$ until $2 \mathrm{~m}$ depth, every $0.5 \mathrm{~m}$ until ca. 4-5 m depth, and every 1-3 m until $15 \mathrm{~m}$ depth, and in the deeper parts of a borehole sensor they are reduced to 5-10 $\mathrm{m}$ steps (Brown et al., 2000). The most frequent sensor depth found 
Table 1. Borehole (BH) and active layer (AL) monitoring site distribution in the GTN-P Database.

\begin{tabular}{|c|c|c|c|c|c|c|c|c|c|c|c|c|}
\hline & & Russia & USA/Alaska & Canada & Mongolia & Antarctica & China & Norway & Svalbard & Switzerland & Sweden & Greenland \\
\hline \multirow{5}{*}{$\begin{array}{l}\text { Boreholes per } \\
\text { permafrost zone }\end{array}$} & Continuous & 185 & 121 & 57 & 45 & 1 & 0 & 0 & 29 & 0 & 2 & 5 \\
\hline & Discontinuous & 75 & 71 & 105 & 0 & 1 & 30 & 17 & 0 & 17 & 12 & 3 \\
\hline & Sporadic & 2 & 3 & 29 & 9 & 0 & 7 & 16 & 0 & 0 & 0 & 1 \\
\hline & Isolated & 9 & 0 & 3 & 37 & 0 & 0 & 0 & 0 & 12 & 5 & 1 \\
\hline & Other* & 23 & 6 & 0 & 0 & 70 & 1 & 3 & 1 & 0 & 0 & 1 \\
\hline \multirow{2}{*}{\multicolumn{2}{|c|}{$\begin{array}{l}\text { total BH/country } \\
\mathrm{BH} / \mathrm{km}^{2} / \text { country }\left(10^{-5}\right)\end{array}$}} & 294 & 201 & 194 & 91 & 72 & 38 & 36 & 30 & 29 & 19 & 11 \\
\hline & & 1.7 & 2.1 & 2.0 & 5.8 & 0.6 & 0.3 & 11.2 & 47.6 & 72.3 & 4.3 & 0.5 \\
\hline \multirow{2}{*}{\multicolumn{2}{|c|}{$\begin{array}{l}\text { total AL/country } \\
\mathrm{AL} / \mathrm{km}^{2} / \text { country }\left(10^{-6}\right)\end{array}$}} & 61 & 67 & 31 & 46 & 9 & 11 & 1 & 7 & 2 & 1 & 3 \\
\hline & & 3.6 & 7.1 & 3.1 & 29.4 & 5.8 & 1.2 & 3.1 & 111.0 & 48.2 & 2.2 & 1.4 \\
\hline & & Japan & Italy & Austria & Argentina & Kazakhstan & Iceland & Spain & Germany & Kyrgyztan & Finland & \\
\hline \multirow{5}{*}{$\begin{array}{l}\text { Boreholes per } \\
\text { permafrost zone }\end{array}$} & Continuous & 0 & 0 & 0 & 0 & 0 & 0 & 0 & 0 & 0 & 0 & \\
\hline & Discontinuous & 0 & 7 & 3 & 0 & 5 & 0 & 0 & 0 & 0 & 0 & \\
\hline & Sporadic & 0 & 0 & 0 & 0 & 0 & 0 & 0 & 0 & 0 & 1 & \\
\hline & Isolated & 7 & 2 & 5 & 0 & 0 & 1 & 0 & 2 & 0 & 0 & \\
\hline & Other* & 3 & 0 & 0 & 5 & 0 & 3 & 3 & 0 & 2 & 0 & \\
\hline \multirow{2}{*}{\multicolumn{2}{|c|}{$\begin{array}{l}\text { total BH/country } \\
\mathrm{BH} / \mathrm{km}^{2} / \text { country }\left(10^{-5}\right)\end{array}$}} & 10 & 9 & 8 & 5 & 5 & 4 & 3 & 2 & 2 & 1 & \\
\hline & & 2.7 & 3.0 & 9.5 & 0.2 & 0.2 & 3.9 & 0.6 & 0.6 & 1.0 & 0.3 & \\
\hline \multirow{2}{*}{\multicolumn{2}{|c|}{$\begin{array}{l}\text { total AL/country } \\
\mathrm{AL} / \mathrm{km}^{2} / \text { country }\left(10^{-6}\right)\end{array}$}} & 0 & 0 & 0 & 0 & 3 & 0 & 0 & 0 & 0 & 0 & \\
\hline & & 0 & 0 & 0 & 0 & 1.1 & 0 & 0 & 0 & 0 & 0 & \\
\hline
\end{tabular}

* Other: glacier, no permafrost or unknown; BH: boreholes; AL: active layer sites.

in the GTN-P TSP data sets is $5 \mathrm{~m}$, followed by 1,3 and $10 \mathrm{~m}$ in decreasing order. A linear regression on 180 data sets from 158 boreholes indicates that the overall number of temperature sensors increase with increasing borehole depth. Within the boreholes, the deviation of the numbers of temperature recordings per time unit ranges from 0 to 57 measurements. Due to the applied methods and demanding field work conditions in permafrost areas, the number of measurements per time vary not only from borehole to borehole but also between time series from the same borehole.

To provide sufficient information about the data quality by using the possibilities of the database, this inconsistency must be assessed both qualitatively and quantitatively. Therefore, the GTN-P Secretariat established an IPA action group to develop strategies for profound numerical assessment and control of the GTN-P data quality, which are being discussed at GTN-P NC workshops and in scientific articles (Biskaborn et al., 2015). The GTN-P database at present stage does not apply fully developed quality criteria, meaning that some of the sites will be revised according to the outcome of the IPA action group.

ALT data generally have fewer numbers of potential biases due to the majority of sites performing measurements of summer thaw depths using mechanical probing either in grids or transects, resulting in multiple measurements compared to point locations associated with sites using thaw tubes or temperature boreholes.

\subsection{Metadata completeness}

We assessed the overall metadata completeness for TSP and ALT data sets by calculating the percentage of available fields that are filled in. Figure 3 indicates the percentages of both data types according to the metadata completeness and the establishment (age) of the monitoring site. ALT metadata are generally more complete, with values between 50 and $80 \%$ (average $63 \%$ ). TSP shows a clustered distribution of metadata completeness with most data sets between 31 and $40 \%$ and a second maximum between 61 and $70 \%$ (average $50 \%$ ). Metadata fields (Fig. 2) with the most missing information are accessibility, distance from disturbance, bibliographic references, terrain morphology, hydrology, slope and aspect, borehole diameter, and permafrost thickness. While these "extra" information are not essential for the direct permafrost monitoring, they are relevant to gain a holistic future view on the thermal state of permafrost by feeding highquality data to global models.

The complex nature of ALT grid metadata, however, created inconsistencies in the structure of the primary data files. Even though the files were standardized before implementation, the low resolution of a number of CALM grid references and TSP borehole coordinates led to imprecise geopositioning: 275 longitudes (20.4\%) and 287 latitudes (21.0\%) have less than four decimal places. A total of 374 data sets $(27.8 \%)$ had coordinates with decimal degree precision below four decimal places of either the latitude or the longitude or both. While these data sets are being successively revised by the NCs, coordinates will be allocated more precisely.

\subsection{TSP borehole depth distribution}

We divided the GTN-P borehole depth classes into $1 \mathrm{~m}$ bins after Burgess et al. (2000). As Fig. 7 shows, the greatest number $(42.3 \%)$ of all TSP boreholes belong to the surface class 


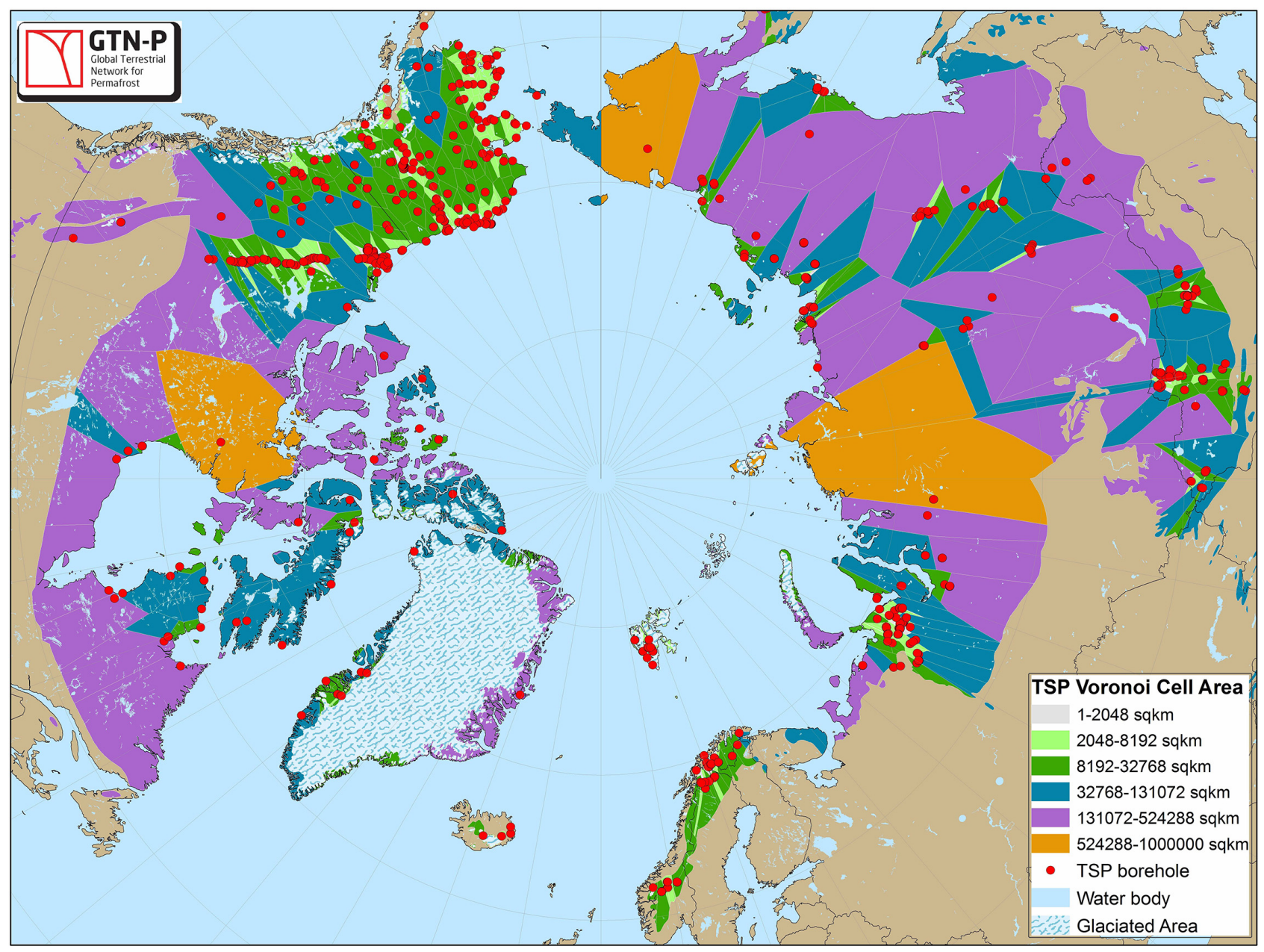

Figure 4. Voronoi tessellation analysis on the distribution of TSP boreholes in the Arctic.

("SU", < $10 \mathrm{~m})$. In general, there are more shallow (30.6\% "SH", 10-25 m) and intermediate boreholes (17.8\% "IB", $25-125 \mathrm{~m}$ ) than deep boreholes (9.3\% "DB", > $125 \mathrm{~m})$. The peaks in the borehole depth distribution correspond to commonly chosen depths $(3,5,10,15,20,25$ and $30 \mathrm{~m})$. These were often defined prior to drilling to capture specific permafrost features such as the depth of zero annual amplitude (DZAA). Deep boreholes are generally older than shallow boreholes. The average drilling dates (year) for the GTN-P depth classes are as follows: SU, 2003; SH, 1997; IB, 1993; DB, 1984. The overall average drilling date of boreholes is 1997. However, only $82 \%$ of TSP data sets contain metadata information about borehole ages. The lack of age metadata affects all depth classes. The average borehole depth of all sites is $53 \mathrm{~m}$, and that of data sets without age information is $29 \mathrm{~m}$. The oldest borehole currently present in the database is located in Russia (Vorkuta K-887) and was drilled to $85 \mathrm{~m}$ depth in 1957.

\section{Spatial analysis and potential of the GTN-P data set}

\subsection{Spatial distribution of TSP and ALT sites}

Table 1 summarizes the distribution of boreholes and active layer monitoring sites per country. The total numbers per country and permafrost zone were calculated by plotting the sites as points and the areas as polygons in ArcGIS. During the analyses some polygons and site coordinates suffered from inaccuracy - for example, terrestrial boreholes with imprecise coordinates were shown as "offshore" sites. In these cases, land-ocean polygon boundaries were slightly shifted and the land polygons extended to capture the relevant points. For calculating the borehole per area ratios, however, we used the original polygon dimensions. The NCs will refine imprecise coordinates during revision of the metadata of their countries. The sites are still included in the analysis due to negligible bias on a hemispheric or Arctic scale.

In order to measure the degree of inhomogeneous sampling and to identify the main geographical gaps with focus 


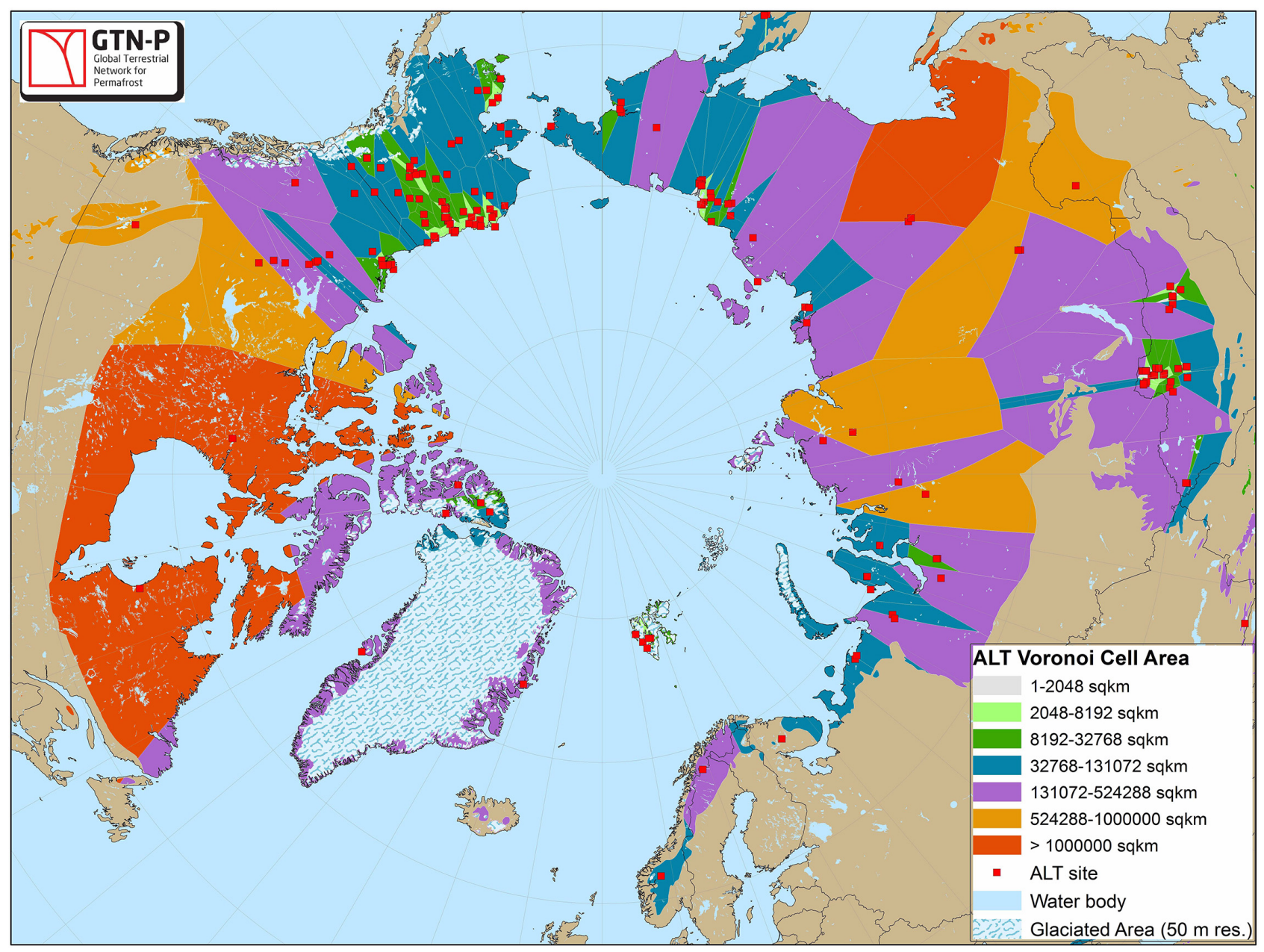

Figure 5. Voronoi tessellation analysis on the distribution of active layer monitoring sites (ALT) in the Arctic.

on the Arctic, we performed a numerical quantification of the distribution of boreholes and active layer grids in the Northern Hemisphere with the help of a Voronoi tessellation analysis (VTA) as suggested by Molkenthin et al. (2014). This analysis demonstrates the potential of the GTN-P Database for assessing the monitoring of permafrost on a hemispheric scale. However, the metadata quality must be successively improved with the help of the NCs and more data must be provided from the international permafrost community to gain a complete and accurate evaluation.

To reduce the potential bias that results from multiple boreholes or active layer monitoring grids around the same coordinate or which are very close to each other, buffers of $1 \mathrm{~km}$ radius for each coordinate were created in $\mathrm{Ar}$ cGIS. Sites with site-to-site distance of $\leq 2 \mathrm{~km}$ were merged and the gravitational centers of the resulting buffer areas were converted to points for further calculations. With the help of this method we reduced 1074 TSP coordinates to 614 buffered TSP sites and 243 ALT coordinates to 187 buffered ALT sites. Glaciated areas (shapefile from Nat- ural Earth data, $50 \mathrm{~m}$ resolution) were removed from the analysis. Voronoi cells were calculated using the Thiessen polygon tool and subsequently clipped to the extension of the IPA map of permafrost zones.

The VTA creates a mosaic by drawing area (cell) boundaries exactly in the middle between neighboring nodes: TSP sites (Fig. 4) and ALT sites (Fig. 5). Every point within a cell is closer to its node than to any other node. In a VTA, uniform distribution of sites would result in maximum peak in the cell size distribution at the same value as $A_{\text {total }} / N_{\text {cells }}$ (Molkenthin et al., 2014), which is basically the same as the mean Voronoi cell size. Hence, to quantify the overall deviation from equidistant sampling of the terrestrial Northern Hemisphere permafrost and glacier-free area, we used the standard deviation (SD) of the Voronoi cell size distribution from TSP (SD: $9.08 \times 10^{4} \mathrm{~km}^{2}$ ) and ALT (SD: $8.68 \times 10^{4} \mathrm{~km}^{2}$ ). For visualization, we calculated the number of Voronoi cells in a cubic size sequence $x^{2}$ ( 1 to 2,2 to 4,4 to $8, \ldots$, $1.05 \times 10^{6}$ to $2.10 \times 10^{6} \mathrm{~km}^{2}$ ) and plotted the results on a logarithmic scale (Fig. 6). Voronoi cell size ranges were at- 


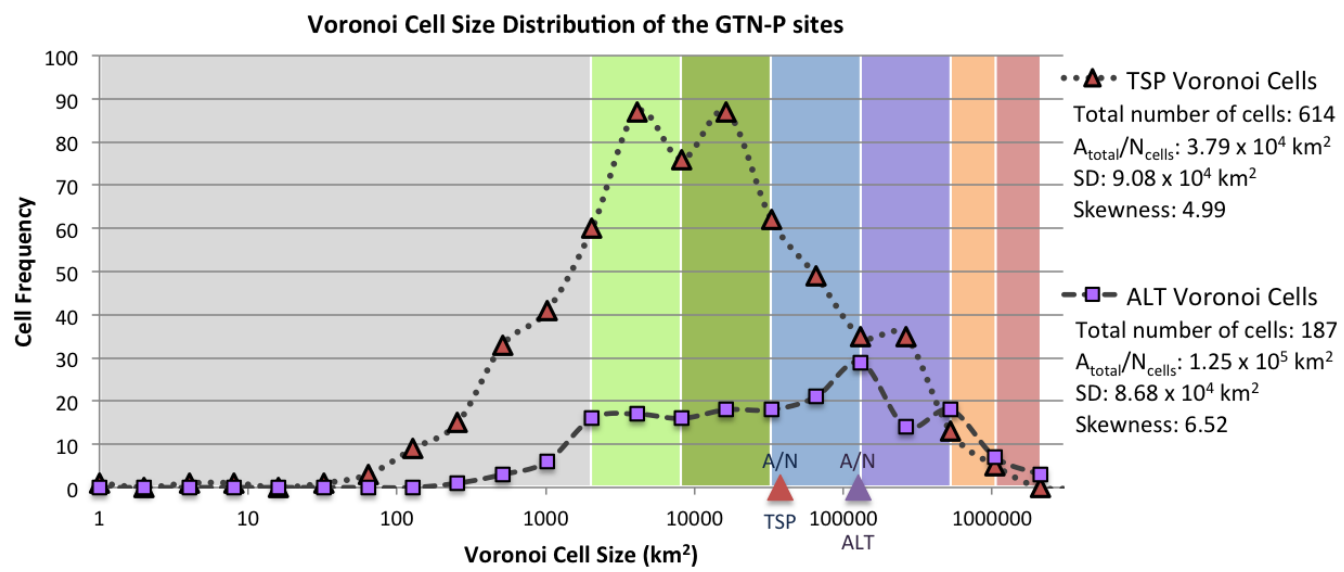

Figure 6. Voronoi cell size distribution according to the Voronoi tessellation analysis on the spatial distribution of boreholes (TSP) and active layer sites (ALT).

Borehole depth distribution (1 m classes)

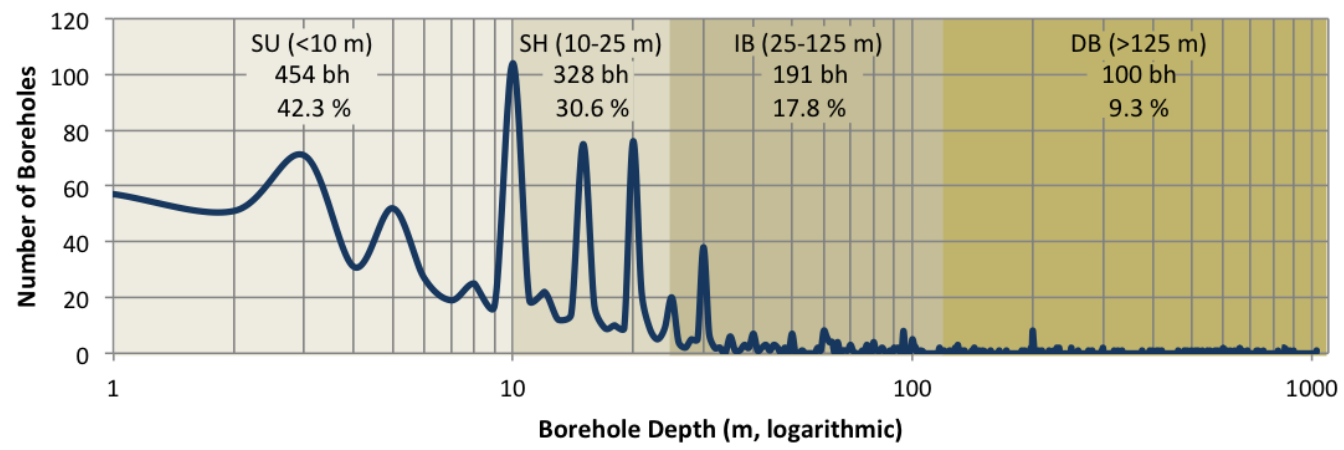

Figure 7. Total numbers of TSP boreholes (bh) and percentages of the GTN-P depth classes: < $10 \mathrm{~m} \mathrm{SU}$ (surface), 10-25 m SH (shallow), 25-125 m IB (intermediate borehole), and > $125 \mathrm{~m} \mathrm{DB}$ (deep borehole).

tributed to the same color types as in Figs. 4 and 5. According to the VTA, the TSP cell size distribution peaks two times at smaller values than the $A_{\text {total }} / N_{\text {cells }}=3.79 \times 10^{4} \mathrm{~km}^{2}$, indicating a significantly clustered sample distribution. TSP bimodal size distribution is attributed to (i) linear spatial sample configuration along transportation corridors in areas with developed economic and infrastructure as well as several high-density borehole transects and (ii) to the good coverage and high number of boreholes in Alaska, both indicated in green. The ALT cell size peaks at about the same values as $A_{\text {total }} / N_{\text {cells }}=1.25 \times 10^{5} \mathrm{~km}^{2}$. The plateau between $2 \times 10^{4}$ and ca. $6 \times 10^{5} \mathrm{~km}^{2}$, however, indicates a clustered sample distribution, although the panarctic ALT sampling is clustered to a lesser degree than the borehole configuration. High skewness of both TSP (4.99) and ALT (6.52) cell size distributions indicates that the peaks are inclined towards higher cell size values demonstrating inhomogeneous sample distribution.

The boundaries of the bigger Voronoi cells (orange and red) and especially their intersections (Figs. 4, 5 and 8) indicate locations with the highest potential for improving the representativeness of permafrost monitoring from hemispherical perspective. Furthermore, these methods can facilitate the planning and establishment of new permafrost monitoring sites in the context of climate change by establishing boreholes and ALT sites where lines intersect with high soil organic carbon content and the transitional zone from continuous to discontinuous permafrost. However, this statement is based on a purely statistical view of the Northern Hemisphere and is not taking into account disturbances resulting from, for example, water bodies, forest fires, infrastructure, areas of deforestation, urbanization, farming, mining and wetland drainage.

\subsection{GTN-P site distribution compared with soil organic carbon content and vegetation}

Together with the TSP and ALT Voronoi cell boundaries and simplified permafrost zones, we illustrated the panarctic distribution of soil organic carbon content within the top two meters by using data from the Northern Circumpolar Soil 


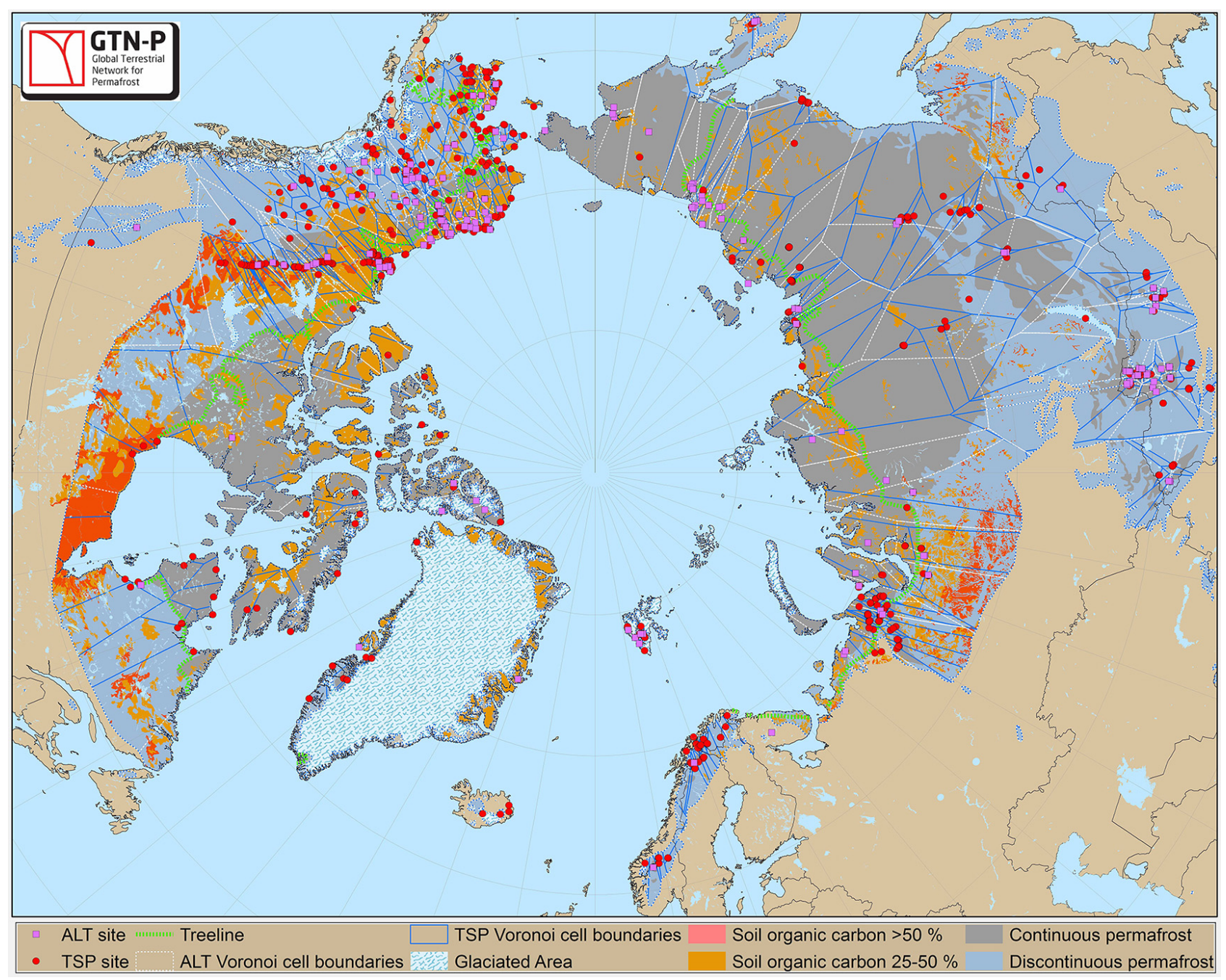

Figure 8. Boundaries of the TSP and ALT Voronoi cells indicate areas with the highest potential of reducing the level of heterogeneity of the site distribution in the Arctic for boreholes and active layer grids, respectively. The map also shows the spatial distribution of permafrost organic carbon content (Hugelius et al., 2013), the treeline (Brown et al., 1998), and the distribution of continuous and discontinuous (including sporadic permafrost and isolated patches) permafrost as well as glaciated areas and water bodies. Where lines intersect with high soil organic carbon content and the transitional zone from continuous to discontinuous permafrost, new permafrost research sites would provide the most important and timely data within the context of recent climate change.

Carbon Database (Hugelius et al., 2013) in Table 2. The distribution of ALT and TSP point coordinates was calculated within the different carbon content groups and shows that, at the circumpolar scale, $25.2 \%$ of all boreholes and almost $29 \%$ of all ALT sites are located in permafrost areas that contain more than $25 \%$ organic carbon. However, only $1.7 \%$ of the boreholes and zero ALT sites cover areas with more than $50 \%$ organic carbon.

We conducted a similar analysis using vegetation zones. For this, we used the vegetation zone information provided in the original GTN-P metadata. Locations with missing vegetation information were attributed to vegetation zones by using photographs of the site (if available) and/or other sources such as atlases of the local flora. This information is provided in Table 2. Because of the wide variety of sources used to define vegetation zones, we prefer not to base recommendations for future locations of monitoring sites based on this information. However, the treeline (Walker et al., 2005), through its function as a major ecotone between forest and tundra, offers high potential for sensitive recording of climate change signals (e.g., Biskaborn et al., 2012) and is therefore shown in Fig. 8 .

\subsection{Preferential slope orientation}

Topography and in particular slope orientation influence the amount of solar radiation received by the ground surface and the accumulation of snow. Due to orbital parameters, 
Table 2. Representation of bioparameters within the borehole and active layer monitoring site distributions. Distribution of soil organic carbon contents in the top $200 \mathrm{~cm}$ from Northern Circumpolar Soil Carbon Database (Hugelius et al., 2013). Vegetation zones taken from the standardized GTN-P metadata.

\begin{tabular}{llrr}
\hline & Bioparameter & TSP boreholes (\%) & CALM grids (\%) \\
\hline & Polar desert & 3.9 & 3.7 \\
& Tundra & 27.3 & 26.9 \\
& Shrub tundra & 11.3 & 13.2 \\
& Grassland & 8.1 & 19.8 \\
Vegetation zone & 11.9 & 12.4 \\
& Forest tundra & 11.4 & 5.8 \\
& Coniferous forest & 2.5 & 1.7 \\
& Deciduous forest & 11.6 & 2.9 \\
& No vegetation & 11.9 & 13.6 \\
\hline Other & 18.4 & 10.7 \\
Soil organic carbon & 20.3 & 22.7 \\
& 0\% or no value & 34.4 & 37.6 \\
& $<10 \%$ & 25.2 & 28.9 \\
& $25-50 \%$ & 1.7 & 0.0 \\
\hline
\end{tabular}

in mountainous regions of lower latitudes, permafrost occurs preferably on north-facing slopes in the Northern Hemisphere. Similarly, in continuous permafrost regions, the active layer is usually thinner on north-facing slopes (French, 2007). To inspect the monitoring bias that might be caused by preferential slope orientation, we analyzed the slope and aspect for boreholes and active layer sites.

Only few of the original GTN-P metadata collections contained slopes and aspects of the ground surface at the permafrost borehole or the active layer grid sites. This information also existed in various formats. We used the ESA DUE Permafrost Circumpolar digital elevation model (Santoro and Strozzi, 2012) in ArcGIS to calculate slope and aspect from the Northern Hemisphere topography. This remote-sensingderived model, however, has a resolution of $100 \mathrm{~m}$, and therefore the calculated values (in degree units) for each site north of $60^{\circ} \mathrm{N}$ should be evaluated carefully. Figure 9 shows the slopes and aspects and their statistics for the original metadata and the calculated values in spherical projections plotted with STEREONET 9.2 (Cardozo and Allmendinger, 2013). The graph includes both surface areas at TSP and ALT sites as (i) planes in equal-angle projections and (ii) the frequencies of slope aspects as rose diagrams with a bin size of $30^{\circ}$. A comparison between the original metadata and the DEMderived values shows major differences in the ALT sites, amplified (i) by the very low number of slope metadata entries $(n=8)$ and (ii) due to the fact that most active layer monitoring sites are located on a more or less flat terrain. It must be considered, however, that the majority of ALT sites are established in zonal geophysical conditions typically found on flat watersheds and only a few historically adapted sites are located on slopes or in complex terrain.

The closer the slope values are to zero, the higher the potential uncertainty in the aspect values. Aspects in the orig-

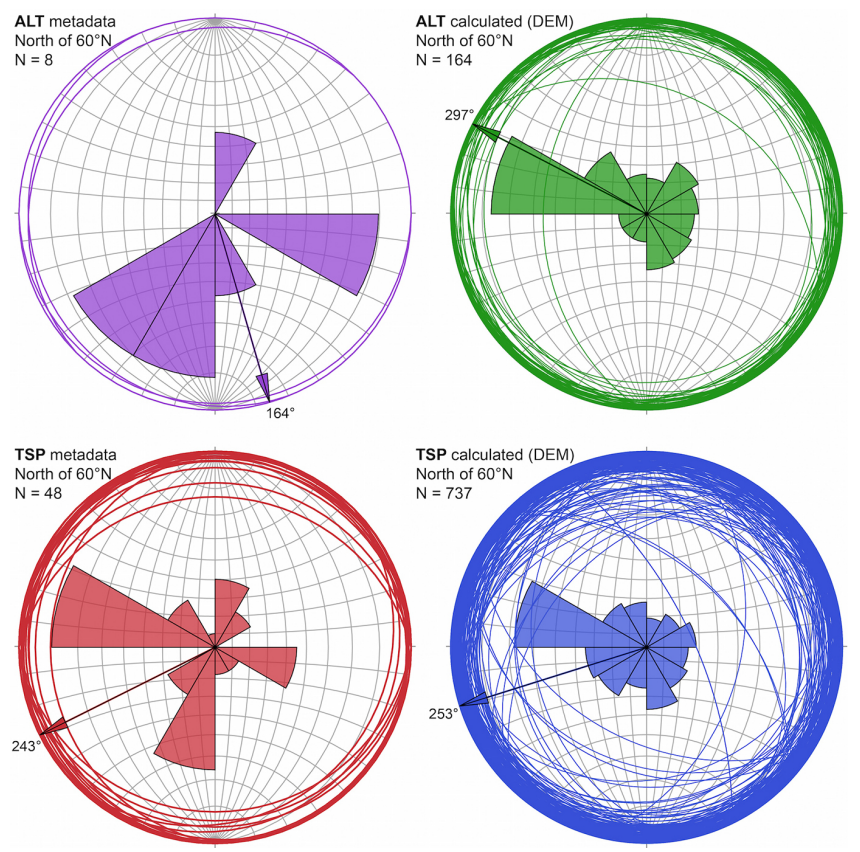

Figure 9. Terrains at TSP and ALT as spherical equal-angle projections in stereonets and the frequencies of slope aspects as a rose diagram with bin size of $30^{\circ}$. Circle lines represent sutures of planes (site terrain) and their orientation.

inal TSP and ALT metadata had various formats including verbal descriptions and abbreviations of main (rough) geographical directions. Accordingly, these rose diagrams and planes are concentrated in categorized directions such as $\mathrm{N}$, NW and WNW. A higher overall number of TSP borehole slopes and aspects $(n=48)$ from the metadata than for ALT sites enabled a more reliable comparison between original 


\section{GTN-P sites per zone of projected temperature change}

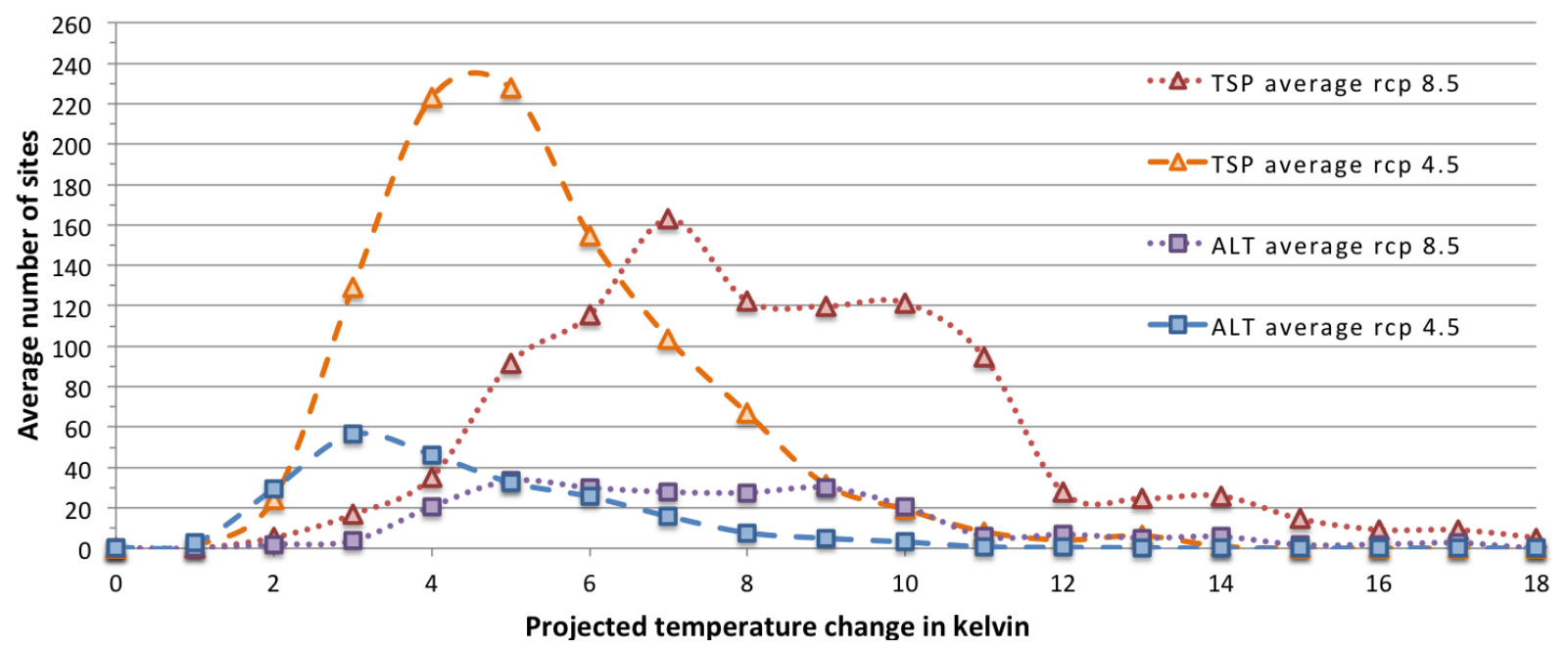

Figure 10. Average number of GTN-P sites within zones of projected temperature change calculated from 15 climate models: ACCESS1-0, bcc-csm1-1, CanESM2, CCSM4, CNRM-CM5, CSIRO-MK3-6-0, GISS-E2-H, GISS-E2-H, GISS-E2-R, HadGEM2-ES, inmcm4, IPSLCM5A-LR, MPI-ESM-LR, MRI-CGCM3 and NorESM1-M. rcp: representative concentration pathway. KML files for visualization of the TSP and ALT locations and the listed climate models in Google Earth are available at www.gtnp.org.

and calculated values. For all TSP sites north of $60^{\circ} \mathrm{N}, 25 \%$ of the original metadata and $20 \%$ of the DEM-derived data rank in the bin between 271 and $300^{\circ}$. Both mean vectors point towards a WSW direction, as indicated in Fig. 9 by the arrows. The fact that slopes at the borehole and ALT sites are dipping towards a preferential direction indicates that there is a different amount of incoming solar energy received by the monitored ground than compared to the average. Therefore, preferential slope orientation causes a bias in the overall representativeness of temperature monitoring and should be taken into account when using the data for global models.

\subsection{The distribution of GTN-P sites within zones of projected temperature change}

Climate models project temperature increases in the Arctic towards the end of the 21st century that are larger than anywhere else on Earth (ACIA, 2004; IPCC, 2013). CMIP5 models show that, for each degree of global temperature increase, about $1.6 \times 10^{6} \mathrm{~km}^{2}$ or ca. one-quarter of the present near-surface permafrost area is expected to start to disappear (Koven et al., 2013) and boreal landscapes will most likely lose all present discontinuous permafrost zones by the end of the 21st century (Slater and Lawrence, 2013). To assess the distribution quality of present permafrost temperature monitoring, we calculated the number of TSP and ALT sites per zone of projected temperature change for 15 different climate models. We created maps showing the spatial distribution of the mean annual near-surface temperature change ( $T$ 2070-2099 minus $T$ 1970-2000) for representative concentration pathways (rcp's) 4.5 and 8.5 using mod- els: ACCESS1-0, bcc-csm1-1, CanESM2, CCSM4, CNRMCM5, CSIRO-MK3-6-0, GISS-E2-H, GISS-E2-H, GISS-E2R, HadGEM2-ES, inmcm4, IPSL-CM5A-LR, MPI-ESMLR, MRI-CGCM3 and NorESM1-M. Thereafter we calculated the number of GTN-P sites per $1{ }^{\circ} \mathrm{C}$ sector. Figure 10 shows that in rcp 4.5, an intermediate greenhouse gas emission scenario, most boreholes and ALT sites are located in relatively narrow zones of less extreme projected temperature change (ca. $3-6^{\circ} \mathrm{C}$ for TSP and ca. $2-5^{\circ} \mathrm{C}$ for ALT). The high-emission scenario rcp 8.5 projects a more extreme temperature increase for larger areas and more GTN-P monitoring sites are located in zones of up to a $10^{\circ} \mathrm{C}$ potential temperature rise. A comparison of the applied models shows that, depending on the model uncertainties and variety of possible climate futures, the spatial distribution of projected temperature change varies from model to model. This is why increasing the number of soil temperature and active layer monitoring sites by filling main geographical gaps is critically important to constrain projections of climate change's impact on permafrost.

\section{Conclusions and perspectives}

The GTN-P Database contains standardized and qualitychecked permafrost temperature and active layer thaw depth data from the Earth's permafrost regions: 1074 TSP boreholes and 243 ALT sites. The GTN-P Data Management System provides automated visualization and data output formats developed for the needs of a wide variety of users including climate modelers. However, the database at present relies on the involvement of permafrost scientists, i.e., na- 
tional correspondents, which are responsible for metadata revision and data quality control. About one-quarter of the present metadata sets still need revision of the site coordinates. On average, TSP and ALT data sets have 50 and $64 \%$ filled-in metadata fields, respectively.

By applying a Voronoi tessellation analyses we demonstrated the potential of spatial statistics performed on the GTN-P metadata set to identify new monitoring sites by reducing gaps in the site distribution related to both spatial homogeneity and environmental parameters. Vegetation types, soil organic carbon content, and the slope orientation at boreholes and active layer depth monitoring sites show the existence of biases and hinder the representativeness of these sites at the global level. The distribution of GTN-P sites according to projected temperature change shows a high representation of areas with smaller expected temperature rise but a lower number of sites within Arctic areas where climate models project extreme temperature rise.

For gaining a representative global view on the thermal development of the Earth's permafrost landscapes, more permafrost monitoring sites must be established at key sites and entered into the GTN-P Database. These sites should be preferentially located in areas where monitoring is lacking, as well as where soil organic carbon contents are high and projected temperature change is high. This paper offers a scientific basis and maps for planning future permafrost research monitoring sites, which could feed into existing planning efforts such as the Global Cryosphere Watch (GCW) Implementation Plan 2015 (http://globalcryospherewatch.org).

Future work focuses on the establishment of data quality control as well as on the conversion of stations distributed data to regular grid data to facilitate their implementation in global models. Thus, the GTN-P Secretariat established an IPA action group to develop a numerical assessment of the TSP and ALT data quality within the framework of international workshops and scientific articles.

Continuous future financial support of the GTN-P Data Management System is crucial to sustain the database and collect and standardize monitoring data over long time spans. The database was initially developed as a result of project related funding, provided by the EU PAGE21 project until now; however, going forward it will seek national long-term support via an institution with a strong emphasis on permafrost.

Author contributions. The lead author, Boris K. Biskaborn (GTN-P Secretariat Director, PAGE21 Scientific Data Manager), wrote the manuscript and performed the statistics. Co-authors JeanPierre Lanckman (GTN-P Secretariat) developed the data management system of the GTN-P database. Hugues Lantuit (PAGE21, GTN-P Advisory Board) was the initiator and main advisor for this study. Kirsten Elger contributed as former GTN-P manager to the database and in the data policy chapter. Dmitry A. Streletskiy (GTN-P Steering Committee) was the main advisor for CALM (ALT) data. William L. Cable (GTN-P Secretariat, national correspondent) was the advisor for technical aspects of boreholes.
Vladimir E. Romanovsky (Chair of the GTN-P Steering Committee) was the main advisor for TSP data.

Acknowledgements. The main sponsor for the establishment of the GTN-P Database is the PAGE21 project, with financial support by the European Commission (FP7-ENV-2011, grant agreement no. 282700). The GTN-P Database was developed and is hosted at the Arctic Portal (Iceland) in collaboration with the Alfred Wegener Institute Helmholtz Centre for Polar and Marine Research (Germany). The authors thank Eleanor Burke and Sarah Chatburn for providing materials and advice on climate models and NetCDF files. We further thank Kerstin Gillen, Almut Dreßler and Kira Rehfeld for their help with technical aspects and data mining. All authors thank two anonymous reviewers for their very good suggestions and comments.

Edited by: M. E. Contadakis

\section{References}

ACIA: Impacts of a Warming Arctic - Arctic Climate Impact Assessment, Cambridge University Press, Cambridge, 2004.

Allard, M., Sarrazin, D., and L'Hérault, E.: Borehole monitoring temperatures in northeastern Canada, v. 1.2 (1988-2014), Nordicana D8, data set, doi:10.5885/45291SL-34F28A9491014AFD, 2014.

Bartsch, A. and Seifert, F. M.: The ESA DUE Permafrost project-A service for high latitude research, in: Proceedings of the Geoscience and Remote Sensing Symposium (IGARSS), 22-27 July 2012, Munich, Germany, 5222-5225, 2012.

Biskaborn, B. K., Herzschuh, U., Bolshiyanov, D., Savelieva, L., and Diekmann, B.: Environmental variability in northeastern Siberia during the last similar to $13300 \mathrm{yr}$ inferred from lake diatoms and sediment-geochemical parameters, Palaeogeogr. Palaeocl., 329, 22-36, 2012.

Biskaborn, B. K., Lantuit, H., Dreßler, A., Lanckman, J.-P., Jóhannsson, H., Romanovsky, V., Cable, W., Sergeev, D., Vieira, G., Pogliotti, P., Nötzli, J., and Christiansen, H. H.: Quality assessment of permafrost thermal state and active layer thickness data in GTN-P. GEOQuébec2015 Conference paper, 2023 September 2015, Québec, Canada, 2015.

Brown, J.: Report from the International Permafrost Association: The IPY Permafrost Legacy, Permafrost Periglac., 21, 215-218, 2010.

Brown, J., Ferrians Jr, O., Heginbottom, J., and Melnikov, E.: Circum-Arctic map of permafrost and ground-ice conditions: National Snow and Ice Data Center/World Data Center for Glaciology, Digital media, Boulder, CO, USA, revised February 2001, 1998.

Brown, J., Hinkel, K., and Nelson, F.: The circumpolar active layer monitoring (calm) program: Research designs and initial results, Polar geography, 24, 166-258, 2000.

Brown, J., Kholodov, A., Romanovsky, V., Yoshikawa, K., Smith, S. L., Christiansen, H. H., Vieira, G., and Noetzli, J.: The Thermal State of Permafrost: the IPY-IPA snapshot (2007-2009), in: Proc. 63rd Canadian Geotechnical Conf. and 6th Canadian Permafrost 
Conf., 12-16 September 2010, Calgary, Alberta, Canada, p. 6. 2010.

Burgess, M., Smith, S., Brown, J., Romanovsky, V., and Hinkel, K.: The Global Terrestrial Network for Permafrost (GTNet$\mathrm{P})$ : permafrost monitoring contributing to global climate observations, Current Research 2000 E14, Geological Survey of Canada, Ottawa, Canada, ISBN 0-660-18219-X, available at: http://wmsmir.cits.rncan.gc.ca/index.html/pub/geott/ess_ pubs/211/211621/cr_2000_e14.pdf (last access: 1 February 2015), 2000.

Cardozo, N. and Allmendinger, R. W.: Spherical projections with OSXStereonet, Comput. Geosci., 51, 193-205, 2013.

Christiansen, H. H., Etzelmuller, B., Isaksen, K., Juliussen, H., Farbrot, H., Humlum, O., Johansson, M., Ingeman-Nielsen, T., Kristensen, L., Hjort, J., Holmlund, P., Sannel, A. B. K., Sigsgaard, C., Akerman, H. J., Foged, N., Blikra, L. H., Pernosky, M. A., and Odegard, R. S.: The Thermal State of Permafrost in the Nordic Area during the International Polar Year 2007-2009, Permafrost Periglac., 21, 156-181, 2010.

DUE Permafrost Project Consortium: ESA Data User Element (DUE) Permafrost: Circumpolar Remote Sensing Service for Permafrost (Full Product Set) with links to datasets, PANGAEA, doi:10.1594/PANGAEA.780111, (new versions 2013, 2014) 2012.

French, H. M.: The Periglacial Environment, John Wiley \& Sons, Ltd., Chichester, UK, 458 pp., 2007.

Groisman, P. and Soja, A. J.: Ongoing climatic change in Northern Eurasia: justification for expedient research, Environ. Res. Lett., 4, 045002, doi:10.1088/1748-9326/4/4/045002, 2009.

Grosse, G., Romanovsky, V., Jorgenson, T., Anthony, K. W., Brown, J., and Overduin, P. P.: Vulnerability and feedbacks of permafrost to climate change, Eos, Transactions American Geophysical Union, 92, 73-74, 2011.

GTN-P: Global Terrestrial Network on Permafrost (GTN-P) Strategy and Implementation Plan 2012-2016, ISSN 2410-2385, International Permafrost Association (and GCOS and GTOS), University of Alaska Press, Alaska, Fairbanks, USA, 32 pp., available at: https://www.wmo.int/pages/prog/gcos/TOPCXV/3. 3_GTN-P_Draft.pdf (last access: 20 August 2015), 2012.

GTN-P: GTN-P metadata for permafrost boreholes (TSP) and active layer monitoring (CALM) sites, data set, PANGAEA, doi:10.1594/PANGAEA.842821, 2015.

Hugelius, G., Tarnocai, C., Broll, G., Canadell, J. G., Kuhry, P., and Swanson, D. K.: The Northern Circumpolar Soil Carbon Database: spatially distributed datasets of soil coverage and soil carbon storage in the northern permafrost regions, Earth Syst. Sci. Data, 5, 3-13, doi:10.5194/essd-5-3-2013, 2013.

IPCC: Climate Change 2013: The Physical Science Basis. Contribution of Working Group I to the Fifth Assessment Report of the Intergovernmental Panel on Climate Change, edited by: Stocker, T. F., Qin, D., Plattner, G.-K., Tignor, M., Allen, S. K., Boschung, J., Nauels, A., Xia, Y., Bex, V., and Midgley, P. M., Cambridge, United Kingdom, and New York, NY, USA, 1535 pp., 2013.

Juliussen, H., Christiansen, H. H., Strand, G. S., Iversen, S., Midttømme, K., and Rønning, J. S.: NORPERM, the Norwegian Permafrost Database - a TSP NORWAY IPY legacy, Earth Syst. Sci. Data, 2, 235-246, doi:10.5194/essd-2-235-2010, 2010.
Koven, C. D., Riley, W. J., and Stern, A.: Analysis of Permafrost Thermal Dynamics and Response to Climate Change in the CMIP5 Earth System Models, J. Climate, 26, 1877-1900, 2013.

Miller, G. H., Brigham-Grette, J., Alley, R. B., Anderson, L., Bauch, H. A., Douglas, M. S. V., Edwards, M. E., Elias, S. A., Finney, B. P., Fitzpatrick, J. J., Funder, S. V., Herbert, T. D., Hinzman, L. D., Kaufman, D. S., MacDonald, G. M., Polyak, L., Robock, A., Serreze, M. C., Smol, J. P., Spielhagen, R., White, J. W. C., Wolfe, A. P., and Wolff, E. W.: Temperature and precipitation history of the Arctic, Quaternary Sci. Rev., 29, 1679-1715, 2010.

Molkenthin, N., Rehfeld, K., Stolbova, V., Tupikina, L., and Kurths, J.: On the influence of spatial sampling on climate networks, Nonlinear Proc. Geoph., 21, 651-657, 2014.

Obe, R. and Hsu, L.: PostGIS in action, Manning Publications Co., Greenwich, CT, USA, 2011.

Papale, D., Agarwal, D. A., Baldocchi, D., Cook, R. B., Fisher, J. B., and van Ingen, C.: Database maintenance, data sharing policy, collaboration, in: Eddy Covariance, Springer, the Netherlands, 2012.

PERMOS: Permafrost in Switzerland 2008/2009 and 2009/2010, Swiss Academy of Sciences, Zurich, Switzerland, 80 pp., 2013.

Romanovsky, V. E., Drozdov, D. S., Oberman, N. G., Malkova, G. V., Kholodov, A. L., Marchenko, S. S., Moskalenko, N. G., Sergeev, D. O., Ukraintseva, N. G., Abramov, A. A., Gilichinsky, D. A., and Vasiliev, A. A.: Thermal State of Permafrost in Russia, Permafrost Periglac., 21, 136-155, 2010a.

Romanovsky, V. E., Smith, S. L., and Christiansen, H. H.: Permafrost Thermal State in the Polar Northern Hemisphere during the International Polar Year 2007-2009: a Synthesis, Permafrost Periglac., 21, 106-116, 2010b.

Santoro, M. and Strozzi, T.: Circumpolar digital elevation models $>55^{\circ} \mathrm{N}$ with links to geotiff images, PANGAEA, doi:10.1594/PANGAEA.779748, 2012.

Schaefer, K., Lantuit, H., Romanovsky, V. E., Schuur, E. A., and Witt, R.: The impact of the permafrost carbon feedback on global climate, Environ. Res. Lett., 9, 085003, doi:10.1088/17489326/9/8/085003, 2014.

Schuur, E. A. G., Abbott, B. W., Bowden, W. B., Brovkin, V., Camill, P., Canadell, J. G., Chanton, J. P., Chapin III, F. S., Christensen, T. R., Ciais, P., Crosby, B. T., Czimczik, C. I., Grosse, G., Harden, J., Hayes, D. J., Hugelius, G., Jastrow, J. D., Jones, J. B., Kleinen, T., Koven, C. D., Krinner, G., Kuhry, P., Lawrence, D. M., McGuire, A. D., Natali, S. M., O’Donnell, J. A., Ping, C. L., Riley, W. J., Rinke, A., Romanovsky, V. E., Sannel, A. B. K., Schaedel, C., Schaefer, K., Sky, J., Subin, Z. M., Tarnocai, C., Turetsky, M. R., Waldrop, M. P., Anthony, K. M. W., Wickland, K. P., Wilson, C. J., and Zimov, S. A.: Expert assessment of vulnerability of permafrost carbon to climate change, Climatic Change, 119, 359-374, 2013.

Shiklomanov, N., Nelson, F., Streletskiy, D., Hinkel, K., and Brown, J.: The circumpolar active layer monitoring (CALM) program: data collection, management, and dissemination strategies, in: Proceedings of the 9th International Conference on Permafrost, 29 June-3 July 2008, Fairbanks, Alaska, USA, 1647-1652, 2008.

Shiklomanov, N. I., Streletskiy, D. A., and Nelson, F. E.: Northern Hemisphere component of the Global Circumpolar Active Layer Monitoring (CALM) Program, in: Proceedings of the Tenth International Conference on Permafrost, 25-29 June 2012, 
Salekhard, Yamal-Nenets Autonomous District, Russia, 377$382,2012$.

Slater, A. G. and Lawrence, D. M.: Diagnosing present and future permafrost from climate models, J. Climate, 26, 5608-5623, 2013.

Smith, S. L., Romanovsky, V. E., Lewkowicz, A. G., Burn, C. R., Allard, M., Clow, G. D., Yoshikawa, K., and Throop, J.: Thermal State of Permafrost in North America: A Contribution to the International Polar Year, Permafrost Periglac., 21, 117-135, 2010.

Van Everdingen, R.: Multi-language glossary of permafrost and related ground-ice terms, National Snow and Ice Data Center/World Data Center for Glaciology, Boulder, CO, USA, updated 2005, 1998.
Vieira, G., Bockheim, J., Guglielmin, M., Balks, M., Abramov, A. A., Boelhouwers, J., Cannone, N., Ganzert, L., Gilichinsky, D. A., Gotyachkin, S., Lopez-Martinez, J., Meiklejohn, I., Raffi, R., Ramos, M., Schaefer, C., Serrano, E., Simas, F., Sletten, R., and Wagner, D.: Thermal State of Permafrost and Active-layer Monitoring in the Antarctic: Advances During the International Polar Year 2007-2009, Permafrost Periglac., 21, 182-197, 2010.

Walker, D. A., Raynolds, M. K., Daniels, F. J. A., Einarsson, E., Elvebakk, A., Gould, W. A., Katenin, A. E., Kholod, S. S., Markon, C. J., Melnikov, E. S., Moskalenko, N. G., Talbot, S. S., Yurtsev, B. A., and Team, C.: The Circumpolar Arctic vegetation map, J. Veg. Sci., 16, 267-282, 2005.

Zhao, L., Wu, Q., Marchenko, S. S., and Sharkhuu, N.: Thermal State of Permafrost and Active Layer in Central Asia during the International Polar Year, Permafrost Periglac., 21, 198-207, 2010 . 